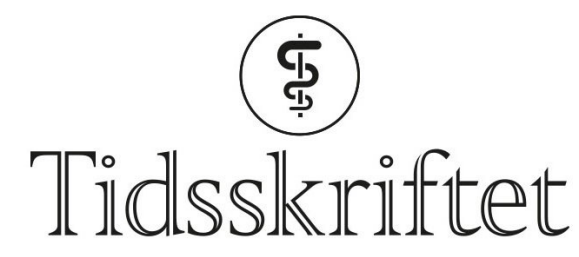

DEN NORSKE LEGEFORENING

\title{
Kjell Rootwelt
}

MINNEORD

JAN G. FJELD

AUD MELBøE

SIGNE ELISE HAGVE

MERETHE WIGEN ANDERSEN

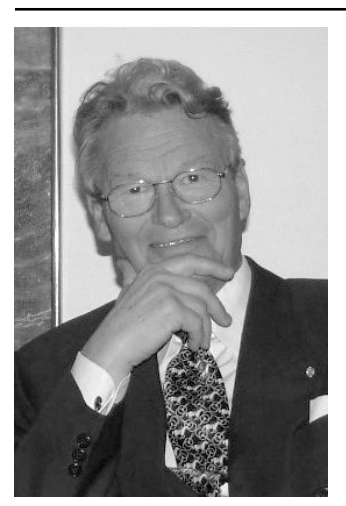

Kjell Rootwelt var født i 1933 og døde 22. august i år, 86 år gammel.

Kjell var overlege ved Nukleærmedisinsk avdeling på Rikshospital og professor ved Universitetet i Oslo. Han vokste opp i Oslo, studerte medisin her og var gjennom hele sitt yrkesliv knyttet til Rikshospitalet. Selv om han nå hadde vært pensjonist siden 2004, føles hans bortgang likevel som et punktum for en viktig periode for nukleærmedisin i Norge.

Gjennom sitt lange virke gjorde han en stor innsats for vårt fagområde ikke bare på sin egen arbeidsplass, men også nasjonalt og internasjonalt. Kjell holdt fast ved nukleærmedisin med alle dets matematiske og naturvitenskapelige utfordringer. Vi som fikk være hans medarbeidere, ser med glede tilbake på flere tiår under hans ledelse ved avdelingen. Vi fikk også nyte godt av hans innsats som innleid pensjonist fram til 2010. Han sørget for at ikke bare legene, men også bioingeniørene, fikk delta ved avdelingens interne møter og undervisning. Det gjaldt også ved nasjonale og internasjonale møter og kongresser. Denne omtalen er derfor skrevet av leger og bioingeniører i fellesskap.

Kjell bygde opp et fagområde som ikke var særlig utviklet da han startet sin yrkeskarriere. Tilgjengelighet og medisinsk anvendelse av radioaktive isotoper økte etter andre verdenskrig. Økt satsing på våpenteknologi under en krig kan ha utilsiktede positive bieffekter. Men det nukleærmedisinske fagområdet var likevel lenge meget avgrenset, oftest som en del av de største sentralsykehusenes medisinske laboratorier. Det var først mot 
slutten av 196o-årene at nukleærmedisinske avdelinger begynte å vokse ved at bildedannende teknologi basert på radioaktivitet ble tilgjengelig. Kjell opplevde dette teknologiske kvantespranget, og han tilegnet seg en grunnleggende innsikt i teknologien. Rikshospitalets nukleærmedisinske avdeling ble under hans ledelse den fremste avdelingen i landet.

Kjell ble utnevnt til første norske professor i nukleærmedisin i 1993 og ble i 2005 tildelt Kongens fortjenstmedalje i gull for sin faglige innsats. Han fikk gitt ut den første og hittil eneste norske lærebok i nukleærmedisin i 1995. Boka er bygd på og følger i stor grad formatet til de prosedyrene han allerede hadde utarbeidet til bruk ved avdelingen. Nettopp dette formatet gjør boka til ikke bare en lærebok, men også en meget nyttig oppslagsbok.

Kjell satte stor pris på sin familie. Vår tanker går til hans kone Vesla, og de tre barna Terje, Helge og Vibeke.

På vegne av alle Kjells medarbeidere ved Nuklecermedisinsk avdeling på Rikshospitalet.

Publisert: 9. november 2020. Tidsskr Nor Legeforen. DOI: 10.4045/tidsskr.20.0828

(C) Tidsskrift for Den norske legeforening 2020. Lastet ned fra tidsskriftet.no 